\title{
PEMEKARAN DAERAH: \\ PELUANG DAN TANTANGAN BAGI PEMEKARAN KOTA MEULABOH
}

\author{
Ikhsan \\ Fakultas Ilmu Sosial Dan Ilmu Politik Universitas Teuku Umar
}

\begin{abstract}
The Establishment of the new city has two consequences. Positive consequence of the creation of new district is the best solution for the old and new in infrastructure development. The negative consequence occure when the creation of new district is only focus on development of new infrastructure for the central office administration and ignore the poverty and welfare as the main problem of society
\end{abstract}

Keywords : Decentralization, Expansion, Poverty 


\section{PENDAHULUAN}

Fenomena pemekaran daerah belakangan ini sangat masif dilakukan dan dibicarakan, termasuk usulan pemekaran Kota Meulaboh menjadi daerah sendiri terpisah dari Kabupaten Aceh Barat. Pemekaran kota Meulaboh menurut banyak kalangan terutama bagi pendukung pemekaran bertujuan untuk meningkatkan pelayanan publik guna mempercepat terwujudnya kesejahteraan masyarakat. Dasar pertimbangan pembentukan daerah adalah berdasarkan pertimbangan kamampuan ekonomi, potensi daerah, sosial budaya, sosial politik, jumlah penduduk, luas daerah, dan pertimbangan lain. Kota Meulaboh yang sudah berhasil menjadi Daerah Otonom Baru diharapkan dapat mengatur dan mengurus kepentingan masyarakat setempat menurut prakarsa sendiri.

Pemekaran daerah merupakan wujud dari keinginan masyarakat di suatu daerah untuk tumbuh dan berkembang dari segi ekonomi, politik, sosial, budaya dan keamanan, dalam dimensi geografis. Tingkat perkembangan wilayah dapat dilihat dari rasio luas wilayah terbangun (built-up area) terhadap total luas wilayah. Semakin besar rasionya, maka semakin tinggi tingkat perkembangan wilayahnya. Kota Meulaboh semakin luas built-up areanya saat ini sehingga dapat diartikan semakin tinggi pula aktivitas ekonomi masyarakatnya. Kondisi tersebut dapat dilihat dari semakin rapatnya jaringan jalan, semakin meluasnya wilayah perkantoran dan perdagangan, semakin menyebarnya wilayah pemukiman dengan kepadatan penduduk yang tinggi dan tingginya peluang kerja.

Kegiatan ekonomi yang semakin meningkat mulai dari pusat-pusat perbelanjaan yang cenderung berkembang mengakibatkan tumbuhnya kota kota satelit sebagai lokasi pemukiman baru. Oleh karena sebuah pemukiman kota baru atau kota satelit membutuhkan luas tanah yang besar dan di dalam wilayah kota sendiri ketersediaan tanah semakin terbatas dan cenderung sangat mahal, maka lokasi kota kota baru tersebut akan menyebar di luar wilayah kota asalnya. Proses inilah yang kemudian menyebabkan wilayah administratif tetangganya memperoleh manfaat dengan semakin berkembangnya daerah perbatasannya. Sebuah daerah yang sudah layak menjadi daerah otonom karena memiliki potensi ekonomi yang memenuhi syarat bagi kehidupan warganya untuk dapat tumbuh dan berkembang tanpa menimbulkan beban keuangan negara, wilayah tersebut akan berkembang sesuai mekanisme pasar.

Tujuan pemekaran daerah adalah untuk : 1) meningkatkan pelayanan dan kesejahteran kepada masyarakat, 2) memperkokoh basis ekonomi rakyat, 3) mengatur perimbangan keuangan daerah dan pusat, 4) membuka peluang dan lapangan pekerjaan dan 5) memberikan peluang daerah mendapatkan investor secara langsung. Pemekaran daerah meliputi pembentukan, penghapusan dan penggabungan daerah atau wilayah harus diarahkan untuk meningkatkan kesejahteraan masyarakat, melalui 1) peningkatan pelayanan kepada masyarakat, 2) percepatan pertumbuhan kehidupan demokrasi, 3) percepatan pelaksanaan pembangunan perekonomian daerah, 4) percepatan pengelolaan potensi daerah, dan 5) peningkatan keamanan dan ketertiban.

Dalam PP Nomor 129 Tahun 2000 syarat untuk dilakukan pemekaran daerah meliputi (i) kemampuan ekonomi; (ii) potensi daerah; (iii) sosial budaya; (iv) sosial politik; (v) jumlah penduduk; (vi) luas daerah dan (vii) pertimbangan lain yang memungkinkan terselenggaranya otonomi daerah. Kota Meulaboh diusulkan untuk menjadi daerah yang otonom sebagai wujud dari aspirasi masyarakat kota yang menginginkan Meulaboh menjadi kota otonom sehingga mampu meningkatkan kesejahteraan masyarakatnya. Di sisi lain, pembentukan Kota Meulaboh juga merupakan bagian dari proses penataan daerah atau teritorial reform/administrative reform. 


\section{METODOLOGI PENELITIAN}

Penelitian ini menggunakan jenis penelitian kualitatif menurut Creswell (2007) yang menjelaskan bagaimana peluang dan tantangan pemekaran Kota Meulaboh. Tujuan dari pemekaran daerah adalah untuk meningkat pembangunan yang tujuan akhirnya untuk mensejahterakan rakyat. Namun demikian, pemkran suatu daerah tidak hanya berimplikasi positif tetapi banyak juga hal negatif . Penelitian ini menggunakan pendekatan studi kasus yang bersifat intrinsic case study yang bertujuan untuk mengetahui lebih mendalam tentang dampak peluang dan tantangan pemekaran Kota Meulaboh.

Penelitian ini akan dilakukan di Kabupaten Aceh Barat Provinsi Aceh untuk melihat bagaimana peluang dan tantangan pemekaran Kota Meulaboh.

Dalam rangka pengumpulan data maka peneliti melakukan pengamatan terlibat dengan cara melakukan interaksi dengan Pemerintah Kabupaten Aceh Barat selaku Daerah otonom induk pemekaran kota Meulaboh sehingga dapat diketahui peluang dan tantangan pemekaran kota meulaboh. Selanjutnya peneliti juga akan melakukan observasi.

Berikut ini merupakan beberapa langkah pengumpulan data yang dilakukan:

\section{Desk Study}

Langkah ini diambil untuk membantu peneliti dalam menemukan, merumuskan, dan memetakan peluang dan tantangan pemekaran kota meulaboh dan dapat membantu peneliti dalam merangkai realitas yang terjadi dengan menggunakan data-data pendukung yang ada. Dengan demikian, maka data dari desk study merupakan data sekunder yang diperoleh dari buku, media massa, laporan penelitian, jurnal, majalah, dan sebagainya.

\section{Field Study}

Langkah selanjutnya dalam pencarian data adalah field study untuk menemukan data primer yang dibutuhkan.Melalui field study, peneliti berinteraksi langsung dengan pemerintah daerah Aceh Barat dan mencari informasi terkait proses pembentukan kota meulaboh. Tujuan dari field study adalah agar peneliti dapat melihat realitas yang terjadi dengan lebih jelas. Hal tersebut tentu hanya dapat diketahui setelah peneliti melakukan pengamatan atau observasi langsung.

Partisipan observation merupakan jenis pengamatan yang melibatkan peneliti dalam kegiatan orang yang menjadi sasaran penelitian tanpa mengakibatkan perubahan pada kegiatan atau aktivitas orang atau informan yang bersangkutan. Dengan kata lain, peneliti mengikuti kegiatan informan dalam waktu tertentu, mendengarkan apa yang dikatakan, mempertanyakan informasi yang menarik, dan mempelajari dokumen yang dimiliki. Tujuan dari pengamatan terlibat ini adalah agar peneliti dapat mencermati bagaimana peluang dan tantangan pemekaran kota meulaboh.

\section{PEMBAHASAN}

\section{Fenomena Pemekaran Daerah di Indonesia}

Pemekaran daerah menghasilkan tren baru dalam struktur kewilayahan di Indonesia. Perkembangan jumlah kabupaten/kota dan propinsi di Indonesia dapat dilihat pada Gambar 1 di bawah. Hingga tahun 2004, terjadi penambahan pemerintah propinsi dari 26 menjadi 33 (26,9 $\%)$ dan pemerintah kabupaten/kota dari 303 menjadi 440 (45,2\%). Pada tahun 2005 pemerintah pusat untuk sementara waktu menangguhkan pemekaran daerah, namun hingga akhir tahun 2006 gejolak usulan pemekaran daerah terus berlanjut. Terdapat usulan pembentukan 114 kabupaten/kota serta 21 propinsi. Kebijakan penangguhan sementara pemekaran daerah selama 2005-2006 sulit bertahan mengingat hingga saat ini belum ada dasar yang kuat. 
Gambar 1 : Jumlah Kabupaten/Kota dan Propinsi Sejak 1999-2006

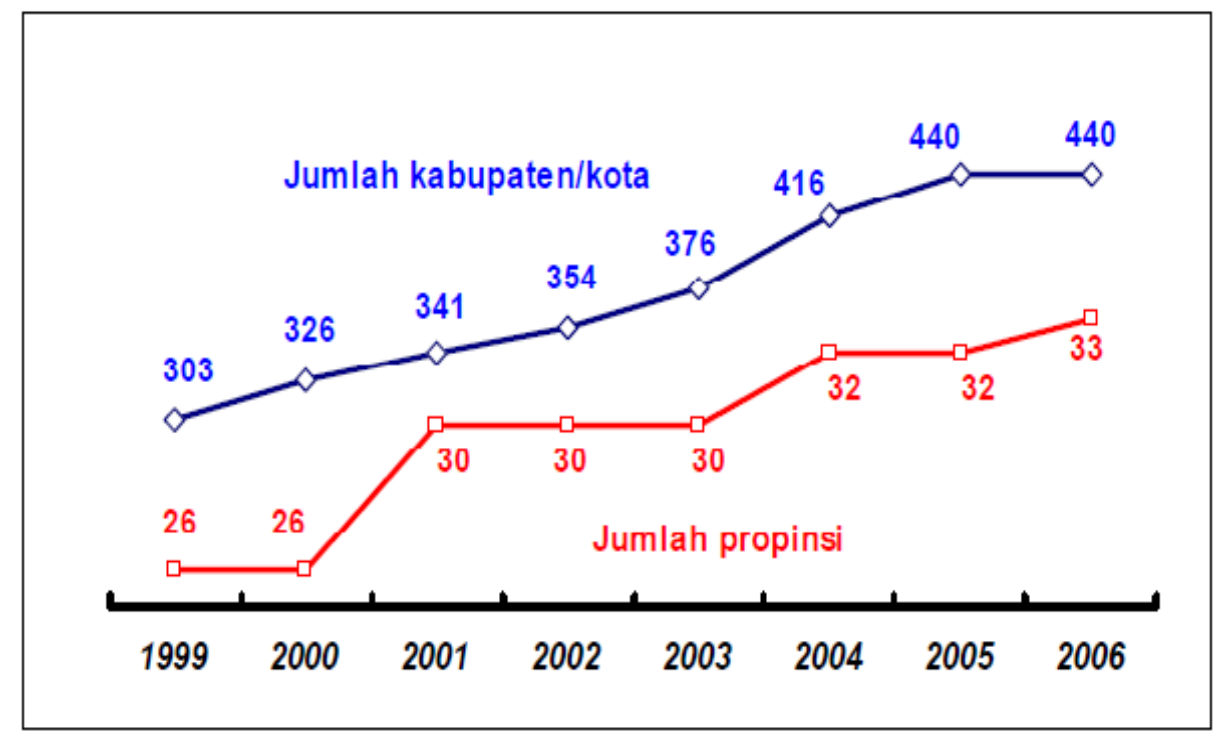

Dari beberapa kajian tentang pemekaran daerah diketahui bahwa terdapat beberapa alasan yang menjadi dasar pengajuan usulan. Alasan tersebut akan dijabarkan secara rinci sebagai berikut.

\section{Alasan Pemekaran Daerah}

Timpangnya Pemerataan Dan Keadilan. Alasan mengapa harus dilakukan pemekaran adalah masyarakat merasakan adanya ketimpangan pemerataan dan keadilan antara satu wilayah dengan wilayah lainnya. Dalam kajian Bappenas bekerjasama dengan UNDP (2008) disebutkan bahwa alasan pemekaran yaitu untuk memberi kesempatan pada daerah untuk melakukan pemerataan pembangunan seperti memperbaiki pemerataan fasilitas di bidang pendidikan, menyediakan lebih banyak tenaga pendidik yang memadai juga mendorong pemerataan pelayanan kesehatan di daerah. Pemekaran daerah juga sering dijadikan alasan untuk mendapatkan keadilan terutama dalam hal pengisian jabatan publik, lapangan pekerjaan, dan peluang usaha.

Kondisi Geografis Yang Luas Dan Pelayanan Masyarakat Yang Tidak Efektif Dan Efisien. Kondisi geografis yang luas juga menjadi alasan pemekaran, wilayah yang memiliki wilayah yang luas dapat menyebabkan tingginya biaya dan usaha yang harus dikeluarkan oleh pemerintah daerah dalam memberikan pelayanan kepada masyarakat, sehingga pelayanan kepada masyarakat menjadi tidak efektif dan efisien.

Perbedaan Civil Society Yang Berkembang Di Masyarakat. Alasan selanjutnya adalah perbedaan kultural atau budaya (etnis), dimana pemekaran daerah terjadi karena dianggap ada perbedaan budaya antara daerah yang bersangkutan dengan daerah induknya atau karena adanya perbedaan basis identitas dalam civil society. Alasan perbedaan identitas (etnis, asal muasal keturunan) juga muncul menjadi salah satu alasan pemekaran. Menurut Cheeman dan Rondinelli (1983) salah satu rasionalitas desentralisasi adalah dalam pembuatan keputusan dan alokasi sumber-sumber yang terwakili oleh bermacam-macam kelompok politik, agama, etnis, dan suku.

Iming-iming insentif fiskal. Adanya iming-iming insentif fiskal yang akan didapatkan setelah pemekaran adalah alasan yang sering digunakan oleh pemegang kekuasaan untuk melakukan pemekaran daerah. Insentif fiskal tersebut antara lain adanya anggaran tersendiri dari pemerintah pusat yang terpisah dari pemerintah daerah induk. Sebagaimana diketahui daerah yang dimekarkan akan mendapatkan anggaran dari daerah induk selama 3 tahun dan 
mendapatkan dana dari pemerintah pusat (DAU dan DAK). Hal ini juga dikemukakan oleh Taufiq C. Dawood (2007) dimana salah satu alasan mengapa pemekaran dilakukan adalah desentralisasi memberikan dana yang lebih besar untuk dapat dikelola oleh setiap pemerintah daerah (khususnya Dana Alokasi Umum).

Pemekaran membuka peluang terjadinya bureaucratic and political rent-seeking, yakni kesempatan untuk memperoleh keuntungan dana, baik dari pemerintah pusat maupun dari penerimaan daerah sendiri. Dari sudut pandang berbeda, pemekaran daerah juga membuka peluang adanya tuntutan untuk menunjukkan kemampuan menggali potensi wilayah, maka banyak daerah menetapkan berbagai pungutan untuk meningkatkan Pendapatan Asli Daerah (PAD). Hal ini menyebabkan terjadinya suatu perekonomian daerah berbiaya tinggi. Lebih jauh lagi timbul pula tuduhan bahwa pemekaran daerah merupakan bisnis kelompok elit di daerah yang sekedar menginginkan jabatan dan posisi.

Status Kekuasaan. Alasan lain dilakukannya pemekaran adalah keinginan elite politik untuk memperoleh status kekuasaan baru atas daerah yang dipimpinnya. Untuk melaksanakan kegiatan pemerintahan di daerah otonomi baru hasil pemekaran daerah maka dibentuk aparat pemerintah daerah baru, hal ini mendorong para calon pemegang kekuasaan di daerah otonomi baru untuk mempercepat pelaksanaan pemekaran daerah. Semangat otonomi daerah telah meningkatkan wewenang pemerintah daerah untuk mengangkat dan memberhentikan pejabat daerah tanpa perlu memperoleh persetujuan pemerintah di atasnya. Pemekaran wilayah juga merupakan salah satu upaya untuk meningkatkan kemampuan pemerintah daerah dalam memperpendek rentang kendali pemerintah sehingga meningkatkan efektivitas penyelenggaraan pemerintah dan pengelolaan pembangunan (Effendy : 2008).

\section{Dasar Hukum Pemekaran Wilayah}

Dalam UU nomor 32 tahun 2004, diatur ketentuan mengenai pembentukan daerah ,dalam BAB II tentang pembentukan dan Kawasan Khusus. Dalam Undang Undang tersebut ada ketentuan bahwa pembentukan suatu daerah harus ditetapkan dengan Undang Undang tersendiri, yang tercantum dalam pasal 4 ayat 1 dan 2 yang sama menyebutkan sebagai berikut, "Undang Undang pembentukan Daerah sebagaimana di maksud dalam ayat 1 antara lain mencakup nama, cakupan wilayah, batas, ibukota, kewenangan menyelenggarakan urusan pemerintahan, menunjukkan pejabat kepala daerah, pengisian keanggotaan DPRD, pengalihan kepegawaian, pendanaan, peralatan, dokumen serta perangkat daerah.

Legalisasi pemekaran wilayah dicantumkan dalam pasal yang sama ayat 3 yang menyatakan bahwa,"pembentukan daerah dapat berupa penggabungan beberapa daerah atau bagian daerah yang bersandingan atau pemekaran dari satu daerah menjadi dua daerah atau lebih", dan ayat 4 menyebutkan "pemekaran dari satu daerah menjadi 2 (dua) daerah atau lebih sebagaimana dimaksud pada ayat 3 dapat dilakukan setelah mencapai batas minimal usia penyelenggaraan pemerintahan".

Pembentukan daerah otonomi baru juga harus memenuhi persyaratan administratif,, tehnis dan fisik kewilayahan. Untuk pembentukan Kabupaen/kota harus mendapat persetujuan DPRD Kabupaten/Kota dan Bupati/walikota bersangkutan, Persetujuan DPRD Provinsi dan Gubernur, serta rekomendasi dari Menteri Dalam Negeri. Kemudian didukung syarat tehnis seperti kemampuan ekonomi, potensi daerah, sosial budaya, sosial politik, kependudukan, luas daerah, pertahanan, keamanan. Kemudian syarat fisik wilayah yang dimaksud meliputi 5 kecamatan untuk pembentukan kabupaten, 4 kecamatan untuk pembentukan kota, dan lima kabupaten untuk pembentukan Provinsi. 


\section{Profil Kota Meulaboh}

Luas wilayah Kabupaten Aceh Barat adalah 2.927,95 km² yang terdiri atas 12 Kecamatan dan jumlah penduduk di Kabupaten Aceh Barat adalah sebesar 172.896 Jiwa dengan kepadatan penduduk sebesar $59 \mathrm{jiwa} / \mathrm{km}^{2}$. Kota Meulaboh sebagai ibu kota Kabupaten Aceh Barat terletak $245 \mathrm{~km}$ tenggara Kota Banda Aceh Pekerjaan sebagian besar penduduknya mencerminkan kehidupan perkotaan, yakni perdagangan dan jasa.

Gambar 3 : Peta Kabupaten Aceh Barat

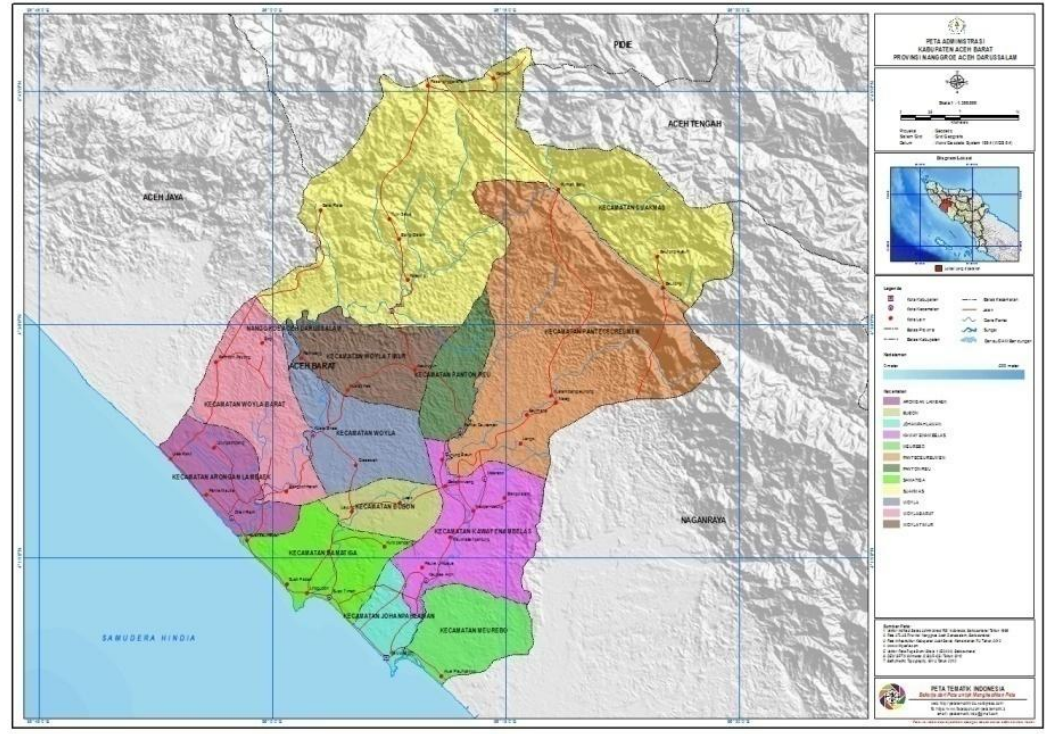

\section{Peluang Pemekaran Kota Meulaboh}

1. Pemekaran Kota Meulaboh dapat berdampak secara sosio kultural. Artinya ialah, pemekaran daerah mempunyai dampak positif seperti memperoleh pengakuan sosial, politik dan kultural terhadap masyarakat daerah. Selain itu, pemekaran daerah menciptakan kepuasan masyarakat, dukungan daerah terhadap pemerintah nasional, serta menjadi alat untuk mencegah dan cara manajemen konflik antar kelompok atau golongan dalam masyarakat.

2. Dari dimensi pelayanan publik, pemekaran daerah memperpendek jarak geografis antara pemukiman penduduk dengan sentra pelayanan, terutama ibukota pemerintahan daerah. Pemekaran juga mempersempit rentang kendali antara pemerintah daerah dengan unit pemerintahan di bawahnya. Pemekaran juga memungkinkan untuk menghadirkan jenis-jenis pelayanan baru, seperti pelayanan listrik, telepon, serta fasilitas urban lainnya, terutama di wilayah ibukota daerah pemekaran.

3. Pasca terbentuknya Kota Meulaboh sebagai daerah otonomi baru maka akan membuka peluang yang besar bagi akselerasi pembangunan ekonomi di wilayah tersebut dengan pemerintahan sendiri. Bukan hanya infrastruktur pemerintahan yang terbangun, tetapi juga infrastruktur fisik yang menyertainya, seperti infrastruktur jalan, transportasi, komunikasi dan sejenisnya. Selain itu, pemekaran tetap menguntungkan karena akan memperoleh alokasi DAU dalam posisinya sebagai daerah otonom baru.

4. Pembentukan Kota Meulaboh merupakan isu politik nasional yang penting. Bagi masyarakat kota, pemekaran daerah otonom bisa memperbaiki penangan politik nasional di daerah melalui peningkatan dukungan terhadap pemerintah nasional dan menghadirkan pemerintah pada level yang lebih bawah. 


\section{Tantangan Pemekaran Kota Meulaboh}

1. Pemekaran Kota Meulaboh dikhawatirkan akan memicu timbulnya konflik antarmasyarakat, antar-pemerintah daerah yang pada gilirannya juga menimbulkan masalah konflik horisontal dalam masyarakat. Sengketa antara pemerintah daerah induk (dalam hal ini Kabupaten Aceh Barat) dengan pemerintah daerah pemekaran (Kota Meulaboh) terkait hal pengalihan aset dan batas wilayah juga dikhawatirkan menimbulkan ketegangan di dalam masyarakat.

2. Pemekaran Kota Meulaboh juga menimbulkan implikasi negatif bagi pelayanan publik terutama pada skala nasional terutama terkait dengan alokasi anggaran untuk pelayanan publik yang semakin berkurang. Hal ini disebabkan adanya kebutuhan belanja aparat dan infrastruktur pemerintahan lainnya yang bertambah dalam jumlah yang signifikan sejalan dengan pembentukan DPRD dan birokrasi di daerah otonomi baru yaitu Kota Meulaboh.

3. Pemekaran berdampak terhadap pembangunan ekonomi. Namun, hal ini harus dibayar dengan ongkos yang mahal terutama anggaran yang dikeluarkan untuk membiayai pemerintahan daerah, seperti belanja pegawai dan belanja operasional pemerintahan daerah lainnya.

4. Dalam hal pertahanan, keamanan, dan integrasi nasional. Maka, kehadiran pemerintahan daerah otonomi baru seperti Kota Meulaboh ini harus dibayar dengan ongkos ekonomi yang mahal, terutama dalam bentuk belanja aparat dan operasional lainnya. Selain itu, seringkali ongkos politiknya juga bisa sangat mahal, apabila pengelolaan politik selama proses dan pasca pemekaran tidak bisa dilakukan dengan baik. Sebagaimana terbukti pada beberapa daerah hasil pemekaran, ketidakmampuan untuk membangun inklusifitas politik antar kelompok dalam masyarakat mengakibatkan munculnya tuntutan untuk memekarkan lagi daerah yang baru saja mekar. Untuk mempersiapkan upaya pemekaran ini, pemekaran unit pemerintahan terbawah, seperti desa untuk pemekaran kabupaten dan pemekaran kabupaten untuk mempersiapkan pemekaran provinsi merupakan masalah baru yang perlu untuk diperhatikan terutama terkait perpecahan di masyarakat.

\section{SIMPULAN}

Pemekaran wilayah adalah sebuah upaya untuk pengembangan demokrasi lokal melalui pembagian kekuasaan pada tingkat yang lebih kecil. Pembentukan Kota Meulaboh juga dapat dilihat sebagai pembalikan konsentrasi kekuasaan pemerintahan kepada pemerintah dengan wilayah administratif yang lebih kecil yaitu sebuah kota. Hal tersebut untuk memudahkan delegasi kekuasaan atau fungsi kepada jenjang-jenjang yang lebih rendah dalam suatu hierarki teritorial, dimana jenjang tersebut adalah satu dari unit-unit pemerintahan di dalam suatu negara. Penataan daerah mencakup pemekaran, penggabungan, dan penghapusan daerah yang sudah ada. Dan dalam konteks Kabupaten Aceh Barat, maka Kota Meulaboh yang sebelumnya adalah kota administratif bagi Kabupaten Aceh Barat berubah menjadi Kota Meulaboh yang otonom dan mandiri dalam hal pemerintahan dan pelayanan kepada masyarakat.

Hasil evaluasi dari para pakar menunjukkan bahwa Kota Meulaboh sangat urgen untuk dibentuk mengingat Kota Meulaboh adalah kota yang sudah lama berdiri di wilayah baratselatan Aceh namun hingga kini belum mampu berkembang secara maksimal. Padahal Kota Meulaboh adalah kota perdagangan di mana arus ekonomi sangat kencang berlangsung di kota ini. Pelayanan yang diberikan kepada masyarakat baik di bidang pendidikan, kesehatan, dan lain sebagainya belum maksimal karena Kabupaten Aceh Barat memiliki wilayah geografis yang luas karena terdiri atas 12 Kecamatan. Dengan adanya pembentukan Kota Meulaboh maka diharapkan akan terciptanya lapangan-lapangan pekerjaan yang baru dan iklim investasi semakin membaik bagi terbukanya peluang usaha.

Para pendukung fragmentasi daerah atau pemekaran melihat bahwa fragmentasi daerah akan membuat kualitas governance menjadi lebih baik karena mampu mendekatkan institusi 
pemerintah, proses pembuatan kebijakan, dan para penjabat dengan masyarakat. Dalam bahasa yang berbeda pembentukan Kota Meulaboh menjadikan warga kota menjadi lebih mudah untuk berpartisipasi dalam proses pembuatan kebijakan. Selain itu, akuntabilitas dari pemerintah Kota Meulaboh ke depan akan semakin terbuka, efektif, dan efisien karena semakin rendahnya biaya transaksi, biaya internalisasi, dan koordinasi antar wilayah.

\section{REFERENSI}

Fitriani, Fitria, Hofman Bert and Kai Kaser. 2005. Unity in Diversity? The Creation of New Local Government in a Decentralising Indonesia. Bulletin of Indonesia Studies

Gujarati, Damodar N. 1995. Basic Econometrics. Third Edition, McGraw-Hill Inc, Singapore Ida, Laode. 2005. Permasalahan Pemekaran Daerah di Indonesia. Media Indonesia, Jakarta Isnaeni, D. R. 2012. Dampak Pemekaran Daerah terhadap Pengembangan Wilayah Kabupaten Bandung Barat. Bandung : Perencanaan Wilayah dan Kota ITB

Kuncoro, M. 2003. Ekonomi Pembangunan. Yogyakarta : UPP AMP YKPN

Kuncoro, Mudrajad. 2003. Otonomi dan Pembangunan Daerah, PT Gramedia Pustaka Utama : Jakarta

Peraturan Pemerintah Nomor 129 Tahun 2000 tentang Persyaratan Pembentukan Dan Kriteria Pemekaran, Penghapusan Dan Penggabungan Daerah

Peraturan Pemerintah Nomor 78 Tahun 2007 tentang Tata Cara Pembentukan, Penghapusan, Dan Penggabungan Daerah.

Ratnawati, Tri. Pemekaran Daerah. Tambunan, T. 2003. Perekonomian Indonesia, Beberapa Masalah Penting. Jakarta : Ghalia Indonesia

Robert Endi (Ed.) .2004. Kompilasi Undang-Undang Otonomi Daerah \& Sekilas Proses Kelahirannya (1903-2004), Institute for Local Development dan Yayasan TIFA, Jakarta

Undang-Undang Republik Indonesia Nomor 32 Tahun 2004 tentang Pemerintahan Daerah

Undang-Undang Republik Indonesia Nomor 33 Tahun 2004 tentang Perimbangan Keuangan Antara Pemerintah Pusat dan Daerah

Undang-Undang Republik Indonesia Nomor 25 Tahun 2009 Tentang Pelayanan Publik

Widodo, T. 2006. Perencanaan Pembangunan : Aplikasi Komputer (Era Otonomi Daerah). Yogyakarta : UPP STIM YKPN

Wijaya. 2014. Otonomi Daerah Dan Daerah Otonomi. Jakarta : Penerbit Rajawali Pers 